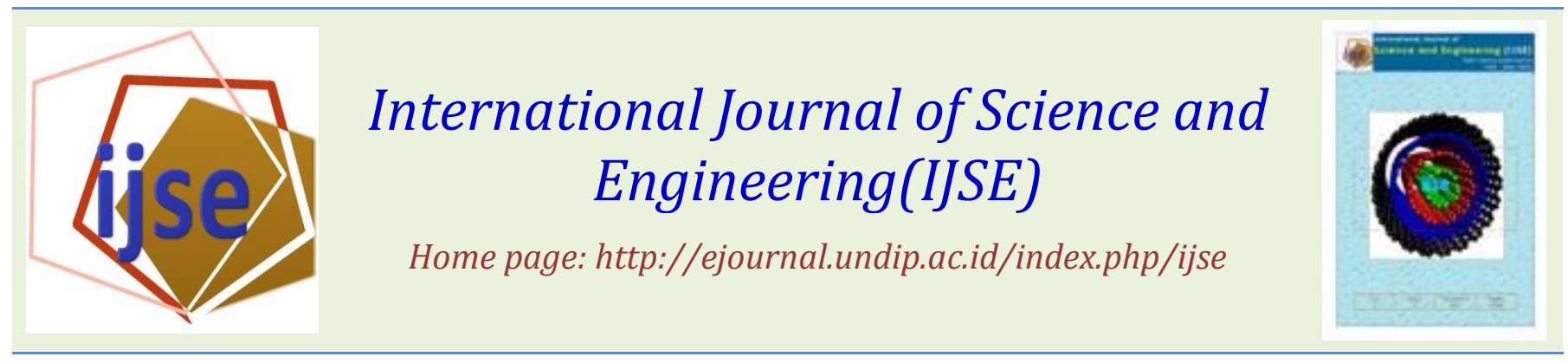

\title{
The Nutrient Digestibility of Locally Sheep Fed with Amofer Palm Oil Byproduct-Based Complete Feed
}

\author{
Hamdi Mayulu\# \\ \#)Animal Feed and Nutrition Laboratory, Faculty of Agricultural Sciences, Mulawarman University \\ Jl. Pasir Belengkong Kampus Gunung Kelua Samarinda 75123 \\ Email: mayoeloehsptno@yahoo.com
}

\begin{abstract}
Utilization of palm oil by-product such as palm fronds, leaves, empty fruit bunches (EFB), fiber fruit juice (FFJ), palm kernel cake $(P K C)$, and palm oil sludge (POS) as the source of energy and protein for ruminants, especially sheep is an efficient effort to make a new opportunities in term of economical and beneficial product that will reduce environmental pollution. The objectives of this research were to analyze the effect of palm oil's byproduct-based complete feed on sheep's nutrient digestibility. Sixteen male sheeps of nine month old with average body weight $14.69 \pm 0.82 \mathrm{~kg}$ were used. The complete feed was formulated by ammoniated-fermented technology from palm fronds and leaves, EFB and FFJ, also Centrosema sp., PKC, POS, ground corn, rice bran, cassava, molasses, urea, mineral mix and salt. The complete feed with different levels of crude protein (CP) and TDN were used in this research which consisted of $T_{1}=10,63 \%$ CP; $63.46 \%$ TDN; $T_{2}=12.27 \%$ CP; $62.38 \% \mathrm{TDN} ; \mathrm{T}_{3}=13.70 \% \mathrm{CP} ; 64.11 \% \mathrm{TDN}$; and $\mathrm{T}_{4}=15.90 \% \mathrm{CP} ; 61.28 \% \mathrm{TDN}$. The study used a completely randomized design (CRD) which consisted of four treatments and four replications. Data was analyzed using ANOVA with significance level at 95\% and followed by Duncan Multiple Range Test. The experimental results showed that the protein level affected the feed digestibility. The highest digestibility of dry matter, organic matter and crude protein were 65.79\%, 70.30\%, and 84.34\% respectively, resulting in $14 \%$ protein level $\left(T_{3}\right)$ were significantly different with treatment at protein level $10 \%\left(T_{1}\right), 12 \%\left(T_{2}\right)$ and $16 \%\left(T_{4}\right)$ at p<0.05. It can be concluded that by-product of palm oil plantation and mill had good nutritional value. Therefore, this feedstuff can be used to formulate complete feed for sheep and it successfully increased the nutrient digestibility.
\end{abstract}

Keywords-Complete feed, sheep, digestibility, palm plantation, palm oil by-product

Submission: May 10, $2014 \quad$ Corrected : June 8, 2014

Accepted: September 1, 2014

Doi: $10.12777 /$ ijse.7.2.106-111

[How to cite this article: Hamdi Mayulu. (2014). The Nutrient Digestibility of Locally Sheep Fed with Amofer Palm Oil Byproduct-Based Complete Feed.,International Journal of Science and Engineering, 7(2),106-111. Doi: 10.12777/ijse.7.1.106-111]

\section{INTRODUCTION}

Forage demand could be fulfilled by utilizing abundant number of agriculture and plantation by-products which processed through feed technology. Palm oil's plantation and mill are potential feed source which produces various and huge amount of by-product. Palm frond, palm leave and palm cover crop are an alternative fresh forage. Empty fruit bunch, palm pressed fiber and palm oil sludge are energy source for production, while palm kernel cake and solid decanter are potential protein source (Utomo and Widjaja, 2004; Azmi and Gunawan, 2005; Maryono and Krishna, 2009). Many of palm oil's by-product is feedstuffs resource with digest-ease concentrate. This utilization is regarded as an effort to make an efficiency in term of production cost but it also requires new technology innovation to manage and improve the nutritional value (Mathius and Sinurat, 2001; Batubara, 2003; Ginting, 2006; Guntoro, 2008).

Through technology approach, many of palm oil's byproduct is potential for feedstuffs applied to sheep.Recent technology shown the promising development of complete feed formulation based on palm oil's byproduct as an alternative feedstuff. In these 10 years, complete feed is wellknown as innovation in ration formulation to overcome feed supply problem. In Indonesia, complete feed technology is potentially used to process a variety of byproducts derived from agriculture and plantation to supply sufficient feed amount for ruminant. Complete feed technology needs a study concerning the appropriate combination and composition to obtain ration formulation which meets the nutrient balance. This study is important because the availability of palm oil's by-product very depends on the field condition and season. Appropriate formula needs to be developed to sustain and maximize the utilization of the resource (Arifin et al., 2009).

Optimization on the uses of by-product derived from agriculture, plantation and agro-industry could lower the cost and increased productivity (Sutrisno, 2001; Hardianto, 2003; Umiyasih and Anggraeni, 2007). Quality optimization of palm oil's by-product can be conducted through ammoniation or fermentation (amofer) which aimed to increase the digestibility, reduce crude fiber content and increase crude 
protein content. One of ammoniation source is urea. Besides of cheap and easy to get, urea is relatively not endanger health and has been commonly used as fertilizer. The characteristics of ideal chemical substance for treatment are effectively increase the digestibility and or intake, cheap, easy to get, do not leave toxic residue which endanger the cattle, fesses and urine don't cause pollution to environment. The material should also be easy to handle and not harmful to raisers. Each kilogram of urea in a certain portion has a positive impact to increase crude fiber intake and digestibility (Caneque et al., 2000; Ribeiro, 2000; Andayani, 2010).

Sheep breeding is a promising livestock agribusiness. Indonesia has local livestock resource which adaptable to hot and humid climate environment. Feed is an important production factor in sheep breeding which will determine the ability of the cattle to express their genetic potency. Feed with sufficient nutritive value esp. the energy and protein, could be obtained from good quality feed. Energy need of sheep is expressed in digestible energy or metabolic energy (Sutama and Budiarsana, 2009).

Digestibility is the availability of nutrients in certain feedstuffs which will be consumed by cattle. High digestibility expressesthe high amount of certain nutrient absorbed by cattle. Low digestibility indicates that the feedstuffs have less ability to supply nutrient for primary needs or production purposes. The ability to digest the feed is determined by several factors such as feed chemical composition and feed preparation. Measuring the digestibility of feedstuff is an effort to determine the nutrient amount contained in a feedstuff which will be degraded and digested in gastrointestinal tract (Coleman and Moore, 2003; Nurhaita et al., 2010).

Low digestibility may be influenced by high content of crude fiber and alkaloid. Research on chemical and biologic treatment have been conducted which proven could increase the feed digestibility. Ammoniation can increase dry matter digestibility and crude protein digestibility that leads to increase feed intake. Microbiologic treatment is able to reduce the fiber content while physical treatment is able to reduce alkaloid level. In addition, ammoniation and fermentation technology could also reduce the fiber content (Mayulu, 2012). The objective of this research was to analyze the influence of amofer palm oil plantation and mill's byproductbased complete feed to sheep's nutrient digestibility.

\section{MATERIAL AND METHOD}

\section{Materials used in this research were:}

1) Complete feed which formulated from amofer palm oil's frond, amofer palm oil's leaves, amofer empty fruit bunch, amofer palm fresh fiber, amofer palm kernel cake, Centrocema sp., corn, rice bran, dried cassava waste pulp, molasses, urea, mineral and salt (Table 1) (Mayulu et al., 2012; Mayulu, 2013).

2) 16 Male of thin tail sheep with aged of \pm 9 months old and average body live weight $14.69 \pm 0.82 \mathrm{~kg}(\mathrm{CV}=5.57 \%)$ were obtained from "Rifkan" animal husbandry, Ngiwon village, Banyuwangi BandunganMagelang.

3) Worm control Vermiprazol 10\%. Individual cage with $150 \mathrm{~cm} \times 75 \mathrm{~cm}$ size. Facilities inside the cage such as feeding and drinking water box, shovel, broom, tarpaulin and water hose.
4) Research instrument such as feed weight scale of Electronic Kitchen Scale Model EK3651 with 5,000 gram capacity and sheep weight scale of Portable Electronic Scale Model DFS 011008 with $40 \mathrm{~kg}$ capacity.

Table 1.Feedstuff Composition and Nutrient Content of a Complete Feed (based on Dry Matter )

\begin{tabular}{lrrrr}
\hline \multirow{2}{*}{ Composition } & \multicolumn{4}{c}{ Treatment } \\
\cline { 2 - 5 } & \multicolumn{1}{c}{$\mathrm{T}_{1}$} & \multicolumn{1}{c}{$\mathrm{T}_{2}$} & \multicolumn{1}{c}{$\mathrm{T}_{3}$} & \multicolumn{1}{c}{$\mathrm{T}_{4}$} \\
\hline Feed Material Contained in CF & $\ldots \ldots \ldots \ldots \ldots \ldots \ldots \ldots \ldots \ldots \ldots \ldots \ldots \ldots \ldots \ldots \ldots \ldots \ldots \ldots \ldots \ldots \ldots \ldots \ldots \ldots \ldots \ldots \ldots \ldots \ldots$ \\
\hline Palm frond & 5.00 & 9.50 & 11.60 & 5.00 \\
Palm leaves & 1.00 & 2.10 & 3.00 & 13.40 \\
Empty fruit bunch & 4.00 & 5.00 & 4.00 & 3.00 \\
Palm pressed fiber & 17.00 & 6.00 & 4.00 & 3.00 \\
Palm oil sludge & 1.00 & 4.00 & 6.00 & 5.00 \\
Palm kernel cake & 10.50 & 10.00 & 10.00 & 4.50 \\
Centrosema sp. & 0.50 & 2.00 & 0.50 & 5.50 \\
Corn & 14.00 & 7.00 & 9.00 & 16.00 \\
Rice bran & 5.00 & 19.10 & 29.00 & 26.00 \\
Dried cassava waste pulp & 40.00 & 33.00 & 20.40 & 16.00 \\
Molasses & 0.50 & 0.50 & 0.50 & 0.50 \\
Urea & - & 0.30 & 0.50 & 0.60 \\
Mineral & 1.00 & 1.00 & 1.00 & 1.00 \\
Salt & 0.50 & 0.50 & 0.50 & 0.50 \\
& 100.00 & 100.00 & 100.0 & 100.00 \\
& & & 0 &
\end{tabular}

Nutrien content of $\mathrm{CF}$

\begin{tabular}{lrrrr} 
Dry matter $^{1}$ & 84.34 & 84.49 & 83.21 & 82.00 \\
Organic matter $^{1}$ & 90.09 & 88.31 & 86.69 & 87.31 \\
Crude protein $^{1}$ & 10.63 & 12.27 & 13.70 & 15.90 \\
Crude fat $^{1}$ & 2.00 & 2.09 & 2.40 & 2.18 \\
Crude fiber $^{1}$ & 22.58 & 24.09 & 22.53 & 25.22 \\
BETN $^{1}$ & 54,88 & 49.86 & 48.05 & 44.01 \\
$\mathrm{TDN}^{2}$ & 63.46 & 62.38 & 64.11 & 61.28 \\
$\mathrm{Ca}^{3}$ & 0.43 & 0.34 & 0.31 & 0.30 \\
$\mathrm{P}^{3}$ & 0.30 & 0.24 & 0.27 & 0.21 \\
\hline
\end{tabular}

${ }^{1}$ Proximate analysis result conducted in Animal Feed and Nutrition Laboratory, Faculty of Animal and Agricultural Sciences, Diponegoro University.

${ }^{2}$ Calculation result (Sutardi, 2001)

${ }^{3}$ Analysis result conducted in Nutrient Biochemical Laboratory, Faculty of Animal and Agricultural Sciences, Diponegoro University.

Completely randomized design with four treatments and four replications at each treatment were used in this research. The treatment was complete feed ratio which included $\mathrm{T}_{1}=10.63 \% \mathrm{CP} ; 63.46 \% \mathrm{TDN} ; \mathrm{T}_{2}=12.27 \% \mathrm{CP} ; 62.38 \% \mathrm{TDN}$; $\mathrm{T}_{3}=13.70 \% \mathrm{CP} ; 64.11 \% \mathrm{TDN} ;$ and $\mathrm{T}_{4}=15.90 \% \mathrm{CP} ; 61.28$ TDN.

Intervention activity was carried out at Laboratory of Laboratory of Animal Feed and Nutrition, Faculty of Animal Husbandry and Agriculture, University of Diponegoro, Semarang under this following procedures: 1) Cleaning the cage, spraying the disinfectant and weighing the initial weight of the sheep. The sheep was randomized into four treatment groups and placed into individual cage. The sheep was orally treated with worm control Vermiprazol $10 \%$ at doses of 2.5 $\mathrm{ml}$ per sheep to avoid the existence of endoparasites especially worms. Prior the test, the sheep was placed into the cage and fed with complete feed for 7 days to eliminate the effect of previous feed so the condition of the sheep was stable. 2) Complete feed was given to the 16 male of thin tail sheep which divided into four groups with four replications. Complete feed diet was offered daily from 07.00 up to 20.00 for 98 days. Weighing and recording of complete feed offered were carried out routinely. The complete feed that was offered 
at the experiment day and the remaining complete feed offered the day before (at 06.00-07.00) were weighted and recorded routinely. Ten days before the final experiment, the remaining feed was collected and taken around 5\% for dry matter analysis. Drinking water was given ad libitum. 3) Fesses within 10 days were collected for nutrient digestibility analysis. Digestibility is a measure of nutrient or complete feed which apparently digested; it is generally expressed as percentage of total intake. Dry matter digestibility is derived from dry matter intake of complete feed $(\mathrm{g})$ deducted with dry weight of fesses which then divided with organic matter weight of complete feed (g) and then multiplied with $100 \%$. Crude protein digestibility is derived from crude protein intake of complete feed $(\mathrm{g})$ deducted with total crude protein content in fesses and then divided with crude protein intake of complete feed and then multiplied with 100\% (Tulloh, 1978; Parakkasi, 1999).

Costat program was used for variance analysis (ANOVA) at significance level of $95 \%$. If there was a significance difference among treatment, the analysis was followed by Duncan Multiple Range Test (DMRT). The optimum point of each variables was determined by polynomial orthogonal equation which resulted from Costat software and displayed in graphic form (Gaspersz, 1994;Supranto, 2006; Gomez and Gomez, 2007).

\section{RESULT AND DISCUSSION}

The result of sheep's nutrient digestibility after consuming complete feed is shown in Table 2. The highest average value of dry matter digestibility, organic matter digestibility and crude protein digestibility was $T_{3}$, followed by $T_{1}, T_{2}$ and $T_{4}$. The result of variance analysis showed that dry matter digestibility, organic matter digestibility and crude protein digestibility of four treatments were significantly different $(\mathrm{p}<0.05)$. According to the result of DMRT, the percentage value of dry matter and organic matter digestibility $(\%)$ at $\mathrm{T}_{3}, \mathrm{~T}_{1}$ and $\mathrm{T}_{2}$ was more significantly different than $\mathrm{T}_{4}$. Meanwhile, the crude protein digestibility (\%) of $T_{3}$ was more significantly different than $T_{1}, T_{2}$ and $T_{4}$. The result of analysis proved that palm oil's byproduct-based complete feed gave positive impact to the sheep's nutrient digestibility.

Digestibility is the percentage of nutrient which absorbed in the gastrointestinal tract. The magnitude of this parameter is known from the difference between the amount of nutrientwhichconsumed and discharged in the form of feses. As the name implies, nutrient that are not found in fesses is assumed as nutrient amount which absorbed and digested (Coleman and Moore, 2003; Rubianti et al., 2007). The research found that the highest dry matter digestibility occurred at $\mathrm{T}_{3}(65.79 \%)$. This finding was better to what had been found by Zain (2007) who stated that dry matter digestibility of male local sheep with 10-14 kg fed with ammoniated palm fiber and supplemented with cassava leave was $57.98 \%$. The maximum value of dry matter digestibility could be estimated based on crude protein treatment which followed this equation: $\mathrm{y}=2,365.646-570.597 \mathrm{X}+46,225 \mathrm{X}^{2}-1,229 \mathrm{X}^{3}\left(\mathrm{R}^{2}=60.93 \%\right)$. Using this equation, the maximum value of dry matter digestibility occurred at crude protein treatment $14.11 \%$ (Figure 1).

Several factors that influence the organic matter digestibility are the species, kind of feed, feeding method, feeding amount and nutrient content (Anggorodi, 1994). The result showed that $T_{3}, T_{1}$ and $T_{2}$ had higher organic matter digestibility compared to $\mathrm{T}_{4}$. This was due to higher crude fiber content in $\mathrm{T}_{4}$. This finding was similar with Tillman et al. (1998) who found that the increasing of crude fiber content which regarded as a component of organic material that are difficult to digest increases the cellulose content.



Figure 1.Dry Matter Digestibility under Different Level of Complete Feed

Table 2.The Average Value of Sheep's Nutrient Digestibility

\begin{tabular}{|c|c|c|c|c|}
\hline \multirow{2}{*}{ Variable } & \multicolumn{4}{|c|}{ Treatment } \\
\hline & $\mathrm{T}_{1}$ & $\mathrm{~T}_{2}$ & $\mathrm{~T}_{3}$ & $\mathrm{~T}_{4}$ \\
\hline DM digestibility & $53.47 \pm 4.53^{\mathrm{a}}$ & $51.67 \pm 9.56^{\mathrm{a}}$ & $65.79 \pm 4.17^{\mathrm{a}}$ & $36.85 \pm 15.20^{\mathrm{b}}$ \\
\hline OM digestibility & $60.79 \pm 4.39^{\mathrm{a}}$ & $58.21 \pm 8.57^{\mathrm{a}}$ & $70.30 \pm 3.50^{\mathrm{a}}$ & $44.60 \pm 12.61^{\mathrm{b}}$ \\
\hline $\mathrm{CP}$ digestibility & $65.32 \pm 4,37^{\mathrm{b}}$ & $64.17 \pm 8,85^{\mathrm{b}}$ & $83.34+1.24^{\mathrm{a}}$ & $62.91+5.69^{\mathrm{b}}$ \\
\hline
\end{tabular}

Organic matter digestibility could be estimated based on crude protein level treatment by using this equation: $\mathrm{y}=$ $2,128,962-509,190 X+41,162 X^{2}-1,092 X^{3}\left(R^{2}=76.55 \%\right)$. According to those equation, the maximum organic matter digestibility occurred at crude protein level of $14.10 \%$ (Figure 2). Total digestible nutrient expresses organic matter amount that can be digested or absorbed. Energy is produced from organic material; therefore TDN of complete feed also expresses the amount of organic matter that can be digested. The increasing of TDN will increase the organic matter digestibility. A combination between digestibility and level of consumption determines the quality of the feed which also acknowledged as indicator of potential livestock production (Coleman and Moore, 2003; Nurhaita et al., 2010). 


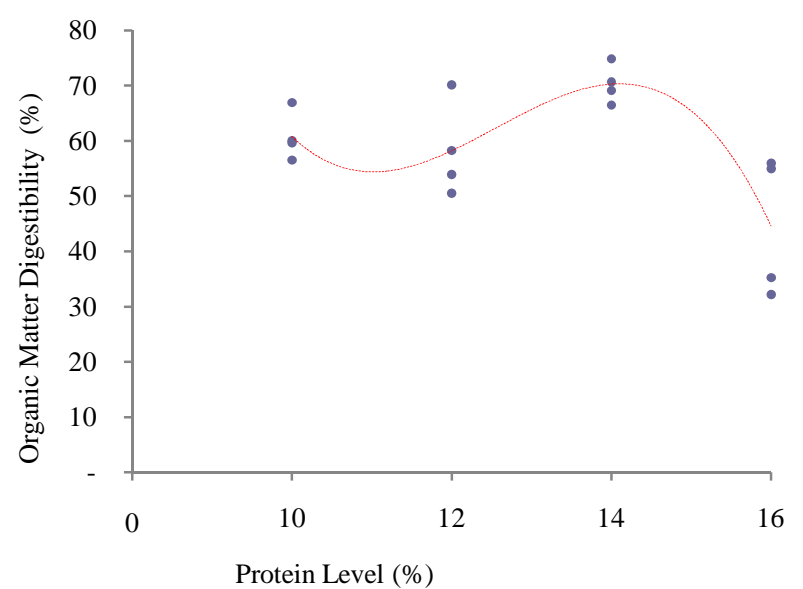

Figure 2.Organic Matter Digestibility under Different Level of Complete Feed

Increased digestibility reflects an increase of number and activity of microorganisms and also followed by an increase of enzyme works. The increasing of protein level contained in complete feed will increase $\mathrm{N}-\mathrm{NH}_{3}$. When TDN is in adequate state, energy and carbon skeleton are expected also sufficient. These two conditions increase the microorganism population and so does the enzyme which then results in an increase of organic matter digestibility. The microorganisms are characterized by proteolytic, cellulolytic, hemicellulolytic, amylolytic, lipolytic and others. This research used complete feed formulation of $11,12,14$ and $16 \%$ which assumed to have been able to provide $\mathrm{NH}_{3}$ concentration in rumen that can support maximum microbial protein synthesis. According to Satter and Slyter (1974), the concentration of ammonia that supports maximum microorganism synthesis is $5 \mathrm{mg} \%$ (5 $\mathrm{ml} / 100$ or $50 \mathrm{mg} / \mathrm{l}$ rumen liquid); 3.57-7.14 mM (Sutardiet al., 1983 ) or equal with $\pm 10 \%$ crude protein and TDN $60-65 \%$ on sheep, $10-12 \%$ crude protein and $60-65 \%$ TDN on cattle (Satter and Roffler, 1981). Orskov (1982) stated that protein biosynthesis of microorganism could reach up to $30-40 \mathrm{~g} / \mathrm{kg}$ of digestible organic matter or equal to $187.5-250 \mathrm{~g}$ protein of microorganism $/ \mathrm{kg}$ of digestible organic matter.

One of popular and effective method to increase the digestibility of crude fiber is ammoniation. The main principle of its work is by damaging or loosening the lignocellulose binding and increasing the solubility of hemicellulose for easier digestion performed by microorganism. Ammoniation also increases the nitrogen content through nitrogen fixation into cell tissues which acts as preservative. Ammoniation process increases digestibility through in vivo, in vitro and in sacco and also increase the feed intake and weight of the sheep. Ammoniation process which supported by urease enzyme at appropriate temperature will hydrolyze the urea into $\mathrm{NH}_{3}$ and $\mathrm{CO}_{2}, \mathrm{NH}_{3}$ will be changed into ammonium hydroxide (Caneque et al., 2000; Ribeiro, 2000; Andayani, 2010).

Ammoniation treatment using urea on complete feed treatment had shown a positive impact on feed material and also the feed digestibility. Ammoniation will be similar to the alkali treatment where $\mathrm{OH}$ group may break the hydrogen bond between oxygen carbon number two of glucose molecule with oxygen carbon number six of others glucose molecule in cellulose, lingo-cellulose and lingo-hemi- cellulose bond. It has been known that the last two bonds is alkali volatile which may be broken by alkali treatment. Feed will expand and easier to be digested by rumen microbe. This expand will dissolve the lignin deposit which presents on cell wall and cell space. Therefore, ammoniation could also reduce the level of difficult-digested substance which then results in the increasing amount of digested feed (Caneque $e t$ al., 2000; Ribeiro, 2000).

Different to ammoniation, fermentation is a process that converts hard structure to softer structure which involves physical, chemical and biological change. Ammoniation process only involves structural change and addition of $\mathrm{N}$ component.Material with complex structure could be changed into simpler structure through fermentation process so the digestibility process will be more efficient (Caneque et al., 2000; Ribeiro, 2000; Andayani, 2010).

Fermentation of palm oil plantation and mill's by-product could be performed effectively with the addition of certain microbe as inoculant. Several types of inoculant and fermenter such as Aspergilus niger, Tricoderma and Rhizoplus is effective for fermenting plantation byproducts. Aspergilus niger is a kind of fungi with facultative characteristic that can grow in aerobic or an-aerobic environment. Therefore, a fermentation process using Aspergillus niger will be more practical since the fermentation process is not necessarily closed (Wina, 2005; Akbar, 2007). A research which employed this fungi had been conducted by the Office of Animal Husbandry Research in Ciawi, Bogor. The research found that crude protein content increased from $12.2 \%$ to $24.5 \%$ of dry matter and metabolic energy content also increased from $1.6 \mathrm{kkal} / \mathrm{g}$ to $1.7 \mathrm{kkal} / \mathrm{g}$. However, an improvement concerning the technology of fermentation is needed to improve the nutrient value (Guntoro, 2005; Mathius et al, 2004; Wina, 2005; Mathius, 2008).

This research found that the highest of crude protein digestibility occurred at $\mathrm{T}_{3}$ with a value of $83.34 \pm 1.24 \%$, followed by $\mathrm{T}_{1}(65.32 \pm 4.37 \%)$ and $\mathrm{T}_{2}(64.17 \pm 8.85 \%)$. The value of crude protein digestibility could be estimated using this equation: : $\mathrm{y}=2,473.326-590,808 \mathrm{X}+47,486 \mathrm{X}^{2}-1,248 \mathrm{X}^{3}\left(\mathrm{R}^{2}=\right.$ $76.55 \%$ ). As a result, the maximum value of crude protein digestibility occurred when the level of crude protein was $14.41 \%$ (Figure 3).

Fast-growing ruminant needs more protein exceeding the capacity of bacteria protein in providing this substance. However, ruminant is able to utilize protein supplement even with low rumen degradation ability. Protein is an essential source for cattle and the availability of adequate protein increases the microorganism activity and growth so the process of digestion and consumption also increase. The protein sources of ruminant are un-degraded feed in rumen, by microbe protein and endogenous protein. The uses of feedstuffs with low degradation ability to produce high yield has attracted much attention in anticipating the sheep performance (Haddad et al., 2005; Rubianti et al., 2007; Silva et al., 2007).

Rumen roles important function for ruminant. An effort to improve the value of feed for ruminant could be carried out through optimizing the performance of microorganism in digestion process. A cellulolytic bacterium which lives inside the rumen is essential to digest fiber-feed. In order to maximize the digestibility of fiber-feed through fermentation, the rumen bacteria should be provided with sufficient nutrient. 
As nitrogen source, ammonia is needed by rumen bacteria to support the growth even the addition of amino acid and peptide can also improve the digestibility of fiber-feed (Zain, 2007).

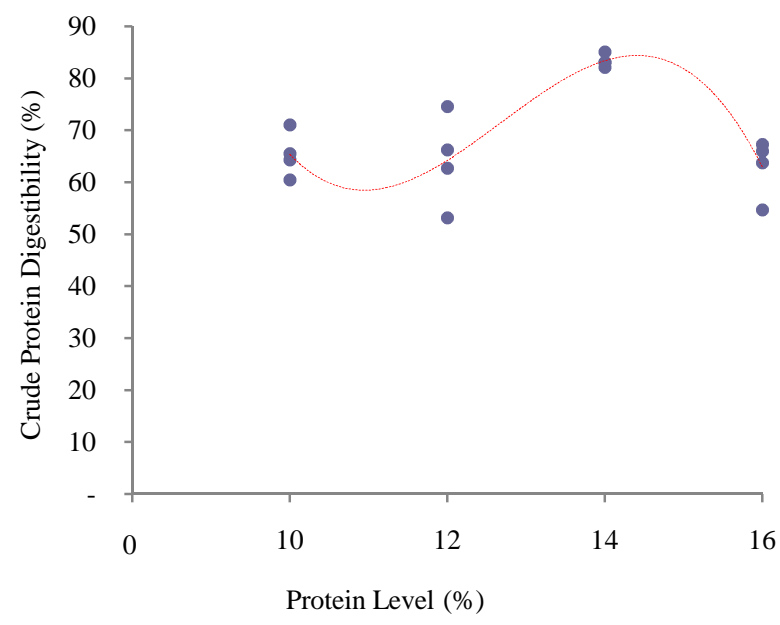

Figure 3.Crude Protein Digestibility under Different Level of Complete Feed

In ruminant, crude protein has two functions: 1) supplying $\mathrm{N}$ for microorganism living in rumen, 2) supplying amino acid to be absorbed in small intestine. Amino acid is supplied from two protein sources i.e. feed protein degraded by microbe and microbial protein from ruminant ammonia assimilation $\left(\mathrm{NH}_{3}\right)$. Those two sources are hydrolyzed to produce amino acid and then absorbed through small intestine for optimum protein biosynthesis. $\mathrm{N}$ substance that can be fermented is converted into ammonia by rumen microorganism. If there is an exceed concentration of $\mathrm{NH}_{3}$ in rumen then this substance will be absorbed into blood and converted into urea in liver. Urea may be freely discharged or returned into rumen through saliva as NPN (Coleman and Moore. 2003; Pittroff et al., 2006).

The optimization of $\mathrm{NH}_{3}$ utilization by rumen microbe requires adequate energy availability which can be obtained from concentrated feed. Principally, high yield of ruminant will be obtained through the support of rumen microbe. The maximum growth of rumen microbe increases the microbial protein supply which absorbed in intestine. Besides, feed should contain good quality of protein which not easily degraded in rumen. Therefore, ruminant gets protein source not only from microbial protein but also from dietary protein. High-fiber feed ingredients in diets fed as protein source could improve the rumen condition (Church and Pond, 2005; Pittroff et al., 2006; Despal at al., 2007; Mahgoub et al., 2007).

The performance of fiber-digested rumen microbe is not optimal when the quality of feedstuffs is low as contained in agriculture and plantation byproduct. The digestibility of agriculture and plantation byproduct could be improved with the addition of urea. Feeding sheep with energy supplementation up to $30 \%$ of the total feed dry matter could increase the feed digestibility by $25.5 \%$ (Kuswandi, 2011).

The nutrient content of palm oil sludge could be increased through aerobic fermentation. Thus, fermentation process is expected to optimize the consumption of feedstuff by improving the nutritive value (crude protein and energy) and reducing the crude fiber content. After fermentation, the nutrient contents particularly the protein content increases. The protein content of palm oil sludge could be increased from $10-11 \%$ to $21-22 \%$. Aerobic fermentation of palm oil sludge could increase the crude protein content up to $43.4 \%$ and energy $2.34 \mathrm{kkal} / \mathrm{gram}$ (Mathius et al., 2004; Mathius, 2008).

As a feedstuff, palm oil sludge could be directly offered or after treated. Palm oil sludge ranging from 10-60\% which fed to sheep could significantly reduce the digestibility coefficient of dry matter, organic matter, protein, crude fiber, fat, beta-n, energy and nitrogen retention. A mixture of pressed fruit fiber and solid with a ratio of 50:50 and fed to sheep at a range of $10-60 \%$ showed that $40 \%$ doses could increase the digestibility of dry matter, organic matter, crude protein, energy and energy retention (Hanafi, 2004).

The development of complete feed is expected to support the effort on providing dietary balanced for ruminants. Balanced nutrient of protein and energy is obtained from balance formulation between fiber-feed source and concentrated feed. Complete feed technology as an alternative of feeding strategy for ruminant could be widely applied in any location to support meat self-sufficiency by 2010 which then revised by 2014 (Wahyono and Hardianto, 2004; Kusnadi, 2008; Mayulu, 2008; Mayulu et al., 2009).

The application of complete feed on fattening cattle could increase the productivity, income, efficiency especially in terms of labor and land use, and fattening period. Complete feed feeding is very efficient as raisers do not need to seek and provide fresh forage as fiber source. The utilization of complete feed will be more efficient if no forage source which occurred during dry season and in dry land area. The introduction of complete feed technology drives the growth and development of community's agribusiness activity particularly in agricultural trading and agro-industrial in supplying the raw material of complete feed. Utilization of complete feed in sheep breeding is quite advantageous in terms of cost, labor and time (Hardianto, 2003; Mahaputra et al., 2003; Mayulu et al., 2009).

\section{IV.CONLUSIONS}

It can be concluded that by-product of palm oil plantation and mill had good nutritional value. Therefore, this feedstuff can be used to formulate complete feed for sheep. It also proved that this effort successfully increased the nutrient digestibility.

\section{ACKNOWLEDGMENT}

The author would like to say thank you to the management board and staffs Laboratory of Animal Feed and Nutrition, Faculty of Animal and Agricultural Sciences, Diponegoro University, for the supports during the research.

\section{REFERENCES}

Akbar, S. A. 2007. Utilization of fermented palm bunches trash combined with defaunation and rumen by pass protein on sheep performance. Journal of the Indonesian Tropical Animal Agriculture 32 (2): 80-85.

Andayani, J. 2010. Evaluation of dry matter, organic matter and crudeprotein in vitro digestibilities of ammoniated corn husk in cattle ration. Journal of Livestock Sciences XIII (5): 252-259.

Anggorodi, R. 1994. General Cattle Feed. PT. Gramedia Jakarta. 
Arifin, M., A. M. Hasibuan, C. M. S. Lestari, E. Purbowati, C. I. Sutrisno, E. Baliarti, S. P. S. Budhi and W. Lestariana. 2009. Edible carcass production of thin tail lambs fed complete feed composed of various agricultural by-products. Jurnal Pengembangan Peternakan 34 (2): 96100.

Azmi and Gunawan. 2005. Potency of forage plantation area for thedevelopment of beef cattle in Bengkulu. In: Subandriyo, K. Diwyanto, I. Inounu, B. R. Prawiradiputra, B. Drtiadi, Nurhayati and A. Priyanti. Proceeding of the National Workshop on Animal Forage. Bogor 16 September 2005. pp. 64-67.

Batubara, L. P. 2003. Potential of animal production integrated withpalm oil estate as an agribusiness based ruminant. Wartazoa13 (3): 83-91.

Caneque, V., S. Valasco and J. L. Sanca. 2000. Nutrional value use of lignocellulosic feed treated with urea in the ruminant diet. Options MediterraneennesSerieSeminaires 16 (1991): 17-31.

Church, D. C and W. G. Pond. 2005. Basic Nutrition and Feeding $5^{\text {th }}$ Ed. CABI Publishing. New York.

Coleman, S. W and J. E. Moore. 2003. Feed quality and animal performance. Field Crops Research 84: 17-29.

Despal, D.A. Astuti, D. M. Suci, D. Evvyernie, I. G. Permata, N. A. Sigitel al 2007. Introduction: Nutrient Science. Department of Nutrient Science and Feed Technology.Faculty of Animal Science. Institut Pertanian Bogor, Bogor.

Gaspersz, V. 1994.Experimental Setup Method. $2^{\text {nd }}$ edition. CV.Armico. Bandung

Ginting, S. P. 2006. Integrated system development of lamb breeding and palm oil plantation (A study on feed availability and nutrient needs).Wartazoa 16: 53-64.

Gomez, K. A. and A. A. Gomez. 2007. Statistical Procedure forAgriculture Research. 2nd edition.UI-Press. Jakarta. (Translated by E. Syamsudin and J. S. Baharsyah).

Guntoro, S. 2008. Producing feed from plantation by-products. Penerbit PT. Agromedia Pustaka. Jakarta.

Guntoro, S. 2005. Processing plantation waste for livestock feed source. Warta Prima Tani1 (1): 8-11.

Haddad, S. G., K. Z. Mahmoud and H. A. Talfaha. 2005. Effect of varying levels of dietary undegradable protein on nutrient intake, digestibility and growth performance of Awassi lambs fed on high wheat straw diets. Small Ruminant Research 58: 231-236.

Hanafi, N. D. 2004. Silage and ammoniation treatment of palmleaves as feed source for sheep. Program study of livestock production, Faculty of Agriculture, Sumatera Utara University, Digitized by USU digital library.

Hardianto, R. 2003. Complete feed formulation technology. In: G.Kartono, Suhardjo, E. Widajati and D Ernawanto (ed). Technical Guide for the Development of Agricultural Technology. Office of Agriculture Technology Application of East Java. p. 109-117.

Kusnadi, U. 2008. Innovation on livestock technology in plant livestock integration system to support meat self-sufficiency. Development of Agricultural Innovation1 (3): 189-205.

Kuswandi. 2011. Local feed utilization technology to improve ruminant production. Pengembangan InovasiPertanian 4 (3): 189-204.

Mahaputra, S., P. Kurniadhi, Rokhman and Kadiran. 2003. Financial analysis of goat production using complete feed. Buletin TeknikPertanian 8 (2): $47-48$.

Mahgoub, O., I. T. Kadim, M. H. Al-Busaidi, K. Annamalai and N. M. Alsaqri. 2007. Effects of fiding ensiled date palm fronds and a by-product concentrate on performance and meat quality of Omani sheep. Animal Feed Science and Technology 135: 210-221.

Maryono and N. H. Krishna. 2009. The advantage and limitation of agriculture byproduct and feeding strategy based on agriculture byproduct for beef cattle. Wartazoa 19 (1): 31-42.

Mayulu, H., B. Suryanto, Sunarso, M. Christiyanto, F. I. Ballo and Refa'i. 2009. Feasibility of complete feed based on ammoniated fermented rice straw utilization on the beef cattle farming. J. Indon. Trop. Anim.Agric 34 (1): 74-79

Mayulu, H. 2013. The nutrient potency of palm oil plantation and mill's byproduct processed with amofer technology as ruminant feed. Internat. J. Sci and Eng. 6 (2): 112-116.

Mayulu, H. 2012. Optimization of palm oil plantation agro ecosystem based ruminant feed resource through complete feed technology. Dissertation Summary, Graduate Program Diponegoro University, Agency Publisher Diponegoro University in Semarang, Semarang.

Mayulu, H., Sunarso, C. Sitrisno and Sumarsono. 2012. The effects of amofer palm oil waste-based complete feed to blood profiles and liver function on local sheep. Internat. J. Sci and Eng. 3 (1): 17-21.
Mayulu, H. 2008. The effects of the use of fermented-ammoniated rice strawbased complete feed on the production and feasibility of beef cattle farming. Universitas Diponegoro, Semarang (Tesis Magister).

Mathius, I. W. 2008. Development of beef cattle based palm oil industry. Development of Agricultural Innovation1 (3): 206-224.

Mathius, I. W., D. Sitompul, B. P. Manurung and Azmi. 2004. Byproductof palm oil plantation and mill as complete feed source for cattle: a review. Proceeding of National Workshop.Department ofAgriculture.

Mathius, I. W dan A. P. Sinurat. 2001. Utilization of inconventional feedstuffs for animal production. Wartazoa 11 (2): 20-31.

Nurhaita, N. Jamarun, L. Warly and M. Zein. 2010. Digestibility of sheep ration with ammoniated palm leaves supplemented with sulfur, phosphor and cassava leaves. Media Peternakan: 144-149.

Orskov, E. R. 1982. Protein Nutrition in Ruminant.Academic Press London.

Parakkasi, A. 1999. Nutrition Scinces and Ruminant Feed PenerbitUniversitas Indonesia (University Press), Jakarta.

Pittroff, W, D. H. Keisler and H. D. Blackburn. 2006. Effects of a highprotein, low-energy diet in finishing lambs: 2. Weight change, organ mass, body composition, carcass traits, fatty acid composition of lean and adipose tissue, and taste panel evaluation. Livestock Science 101: 278-293.

Ribeiro, J. M. C. R. 2000. Treatment of straws. Options Mediterraneennes Serie Seminaires 16 (1991): 55-60.

Rubianti, A., P. Th. Fernandez., H. H. Marawali and E. Budisantoso. 2007. Dry matter and organic matter digestibility of hay clitoriaternatea and centrocema pascourum cv cavalcade of weaned male Bali cattle. page.:18. [Sitasi 10 September 2009]. Available at: http://ntt.litbang.deptan go.id/karya-ilmiah/7.pdf

Satter, L. D. and L. L. Slyter. 1974. Effect of Amonia concentration on rumen microbial protein production in vitro. Br. J. Nutr. 32: 199.

Satter, L. D. and R. E. Roffler. 1981. Influence of nitrogen and carbohidrate inputs on rumen fermentation. (W. Haresign and D. J. A. Cole, Eds.).Recent Developments in Ruminant Nutrition.1 st. Publ. Butterworths London.

Silva, A.M. A., A.G. Silva Sobrinho, I. A. C. M. Trindade, K. T. Resende and O. A. Bakke. 2007. Net and metabolizable protein requirements for body weight gain in hair and wool lambs. Small Ruminant Research 67: 192-198.

Supranto, J. 2006. Operation Research. UI Press, Jakarta.

Sutama, I. K and I. G. M. Budiarsana. 2009. Complete Guide of Goat and Sheep. Penebar Swadaya. Jakarta.

Sutardi, T. 2001. Revitalization of dairy cattle through utilization ofration based estate by-product and organic mineral supplement. Research of RUT VIII.1.Ministry of Research and Technology together with Indonesian Institute of Science, Bogor.

Sutardi, T., N. A. Sigit and T. Toharmat. 1983. Quality Standard of Protein Contained in Ruminant Feedstuff based on the Metabolic Parameter by Rumen Microbe. Project of Science and Technology Development. Directorate of Community Building and Empowerment. Directorate General of Higher Education.

Sutrisno, C. I. 2001. Integration of technology engineering and it simplementation. Journal of Topical Livestock Development. Special Edition: KS 1-9.

Tillman, A. D., H. Hartadi, S. Reksohadiprodjo, S. Prawirokusumo and S. Lebdosoekojo. 1998. The Principal of Livestock Feed Science. $5^{\text {th }}$ edition, GadjahMada University Press, Yogyakarta.

Tulloh, N. M. 1978. Growth, Development, Body Composition, Breeding and Management.In: W. A. T. Bowker, R. G. Dumsdey, J. E. Frisch, R. A Swan and N. M. Tulloh ed., Beef cattle Management and Economics. AAUCS. Academy Press Pty Ltd, Brisbane.

Umiyasih, U and Y. N Anggraeni. 2003. Integrated system of animal and plantation: review of the forage availability for beef cattle in palm oil plantation area. pp. 156-166. [Cited June 2nd 2012]. Available in: http:// peternakan.litbang.deptan.go.id/fullteks/lokakarya/probklu03-16.pdf

Utomo, B. N and E. Widjaja. 2004. Processing of palm oil solid waste asnutrient content for ruminant feed source. Jurnal Litbang Pertanian 23 (1): 22-28.

Wahyono, D. E and R. Hardianto. 2004. Utilization of local feed resources to develop beef cattle (Paper was presented at National Seminar of Beef Cattle 2004). Livestock Research Center and Development, Bogor.

Wina, E. 2005.Technology on utilizing microorganism in feed toincrease ruminant productivity in Indonesia: a review. Wartazoa 15 (4): 173-186.

Zain, M. 2007. Optimization of palm oil fiber as alternative feed source supplemented with cassava leave for ruminant ration. Jurnal Pengembangan PeternakanTropis 32 (2): 100-105 